\title{
Effect Of Recovery Time After Match On Muscle Explosive Power On Football Athletes
}

\author{
Cahyo Bagaskoroํ, Adelia Handoko²* \\ ${ }^{1}$ Student of Faculty of Medicine, Jember University, Jember, East Java, Indonesia \\ ${ }^{2}$ Department of Physiology, Faculty of Medicine, Jember University \\ J1. Kalimantan 37, Kampus Bumi Tegal Boto, Jember, East Java, Indonesia \\ 0331-337877
}

Email: adelia.fk@unej.ac.id

Receive : May $5^{\text {th }}$ 2020. Revised : Apr $1^{\text {th }}$ 2021. Published: June $9^{\text {th }} 2021$

DOI : https://doi.org/10.22219/sm.Vol17.SMUMM1.12092

\begin{abstract}
Football is one of the most prestigious forms of sports that are in great demand by the public. Many football clubs that take part in the competition have a tight match schedule. This causes the recovery time for athletes to be short and lead to fatigue. The purpose of this study was to determine the effect of recovery time after the match on the explosive power of leg muscles in soccer athletes. This study was an experimental study with a pretest-posttest group design. The sampling method used was simple random sampling to get 40 research subjects divided into 2 groups, namely groups with recovery time of 2 days and groups with recovery time of 5 days. The assessment used is measurement of explosive limb muscle power using the vertical jump technique before and after receiving the recovery period. To test the normality of data using Shapiro-Wilk continued with the comparative data test in the form of an unpaired $t$ test. The results of the study in groups with a recovery time of 2 days were worth $-3.7 \mathrm{~cm}$ and the group with a recovery time of 5 days was $2.9 \mathrm{~cm}$. These results were analyzed using unpaired $\mathrm{t}$-test showing $\mathrm{p}$ value $=0,000(\mathrm{p}<0.05)$ which showed there were significant differences between the two groups. The conclusion of this study is that there is an effect of recovery time after the game on the leg muscle explosive power in soccer athletes. Recovery time of 5 days is better than 2 day after competition. It is very important to pay attention to recovery time in athletes, the recommendation of this study is a minimum of 5 days.
\end{abstract}

Keywords : Football, Muscle Explosive Power, Recovery Time.

Copyright (C) 2021, Bagaskoro C. et al This is an open access article under the CC-BY-SA license

\section{INTRODUCTION}

Football is a prestigious sport that is in great demand by Indonesians. Based on survey results in 2014, soccer enthusiasts in Indonesia were 90.7\% (SSI, 2014). Football clubs often participate in several competitions both on an international and national scale at one time, so that the distance between matches that must be traveled by the club becomes close. In addition, soccer clubs also carry out routine training and trials with other teams in preparation for the competition to improve the ability of each athlete. The effect of this problem is schedule of training and 
competitions for athletes become very tight, so the recovery time is short. In soccer, the ability to recover from intense training or match is a key aspect of performance, those who recover faster will have a greater advantage. To ensure adequate recovery after soccer matches and training sessions, it is necessary to know the type of fatigue induced and, if possible, and its underlying mechanism (Carling, 2016; Schimpchen et al, 2016)

This short recovery time can cause fatigue for athletes. Fatigue in soccer athletes can reduce mental performance, kick accuracy, jumping performance and speed so that athlete performance decreases (Smith, 2016; Jimenez, 2017; Larsen, 2018). In addition, a study conducted by Bengtsson et al (2018) states that recovery time of more than 5 days can reduce the risk of muscle injury in athletes by $18-22 \%$ compared to the recovery time of less than 3 days.

Post-match fatigue is caused by several things, dehydration, glycogen depletion, muscle damage, and mental fatigue. One effect that can affect athlete performance is glycogen depletion because glycogen is the main energy source for muscles. Glycogen depletion affects muscle strength. Muscle strength is very necessary for a soccer athlete both during training and during matches, such as kicking a ball and jumping (Wong, 2016). These activities are components of muscle explosive power assessment (Guyton \& Hall, 2016). This research can find out a good recovery time for athletes in order to achieve good performance. For the community, they can arrange a schedule and a portion of their respective exercises to maintain optimal performance. The aim of the research to examine the effect of recovery time after the match on the leg muscle explosive power in soccer athletes.

\section{METHODS}

This research is an experimental research with pretest-posttest group design design. The population in this study were 85 soccer athletes of the Mitratama Club FC and PSIL. The sampling method used was simple random sampling to get 40 research subjects. Subjects were divided into 2 groups, groups with a recovery time of 2 days and groups with a recovery time of 5 days. The inclusion criteria in this study were age 18-29 years old, male sex, midfielder position, Body Mass Index 18.5-24.9 kg / m2, thigh circumference $49-53 \mathrm{~cm}$, not having an injury and / or in the recovery phase of a limb injury, fill informed consent, get approval from the club, healthy. Exclusion criteria in this study were to have a history of central nervous system disorders and / or balance organs, the study subjects did not follow the full research procedure, the Nutrition Adequacy Rate was not enough. This research was carried out in May 2019 to June 2019. The parameter of leg muscle explosive power used was vertical jump assessment before and after the recovery period according to the group. The data obtained were tested for normality using the saphiro-wilk test. Data analysis using unpaired t test. 
Vertical jump measurements require boards, chalk and measuring tape. The measurement procedure is to set the board as high as the estimated ability of the research subjects when standing up to jump, subjects smear their hands with chalk, then give an initial sign using the palm attached to the board when standing as point $A$, then the research subjects jump and attach the palm to the highest point jump as point $\mathrm{B}$, the difference between point $\mathrm{B}$ and point $\mathrm{A}$ is measured using a tape measure and is a vertical jump value.

\section{RESULTS AND DISCUSSION}

This research was conducted in May 2019 to June 2019 with a total of $40 \mathrm{~h}$ subjects. General characteristics of the subjects are presented in Table 1.

Table 1. Characteristics of Subjects

\begin{tabular}{lccc}
\hline Variable & Mean & Maksimum & Minimum \\
\hline Age (years) & 22,9 & 28 & 19 \\
Duration being a soccer athlete & 4,4 & 7 & 3 \\
(years) & & & \\
BMI & $23,0035 \mathrm{~kg} / \mathrm{m}^{2}$ & $24,06 \mathrm{~kg} / \mathrm{m}^{2}$ & $21,24 \mathrm{~kg} / \mathrm{m}^{2}$ \\
\hline
\end{tabular}

Adequate nutritional support after the activity of the athlete is very much needed if the athlete performs sufficient activities with a relatively short amount of time (Vitale, 2019). In this study, the study subjects diet was assessed through a food recall interview and categorized as sufficient if they met the recommended Nutrition Adequacy Rate (RDA) per day for each individual, but this study only counted the total calories consumed by the study subjects without looking at the composition of food ingredients consumed by research subjects. Each subject of this study meets the recommended AKG for each day. The average food recall results for each treatment group are shown in Table 2

Table 2. Mean Calory of Food Recall

\begin{tabular}{ccc}
\hline Day & $\begin{array}{c}\text { Mean calory of recovery time } \\
\text { of } 5 \text { days group }\end{array}$ & Mean calory of recovery time of 5 days goup \\
\hline 1 & $2761,6 \mathrm{kkal}$ & $2803,9 \mathrm{kkal}$ \\
2 & $2779,6 \mathrm{kkal}$ & $2783,4 \mathrm{kkal}$ \\
3 & $2765,8 \mathrm{kkal}$ & - \\
4 & $2741,1 \mathrm{kkal}$ & - \\
5 & $2787,6 \mathrm{kkal}$ & - \\
\hline
\end{tabular}


Table 3. Difference in vertical jump after and before the recovery period of research subjects

\begin{tabular}{lccc}
\hline Parameter & $\begin{array}{c}\text { Mean of recovery } \\
\text { time of } 5 \text { days } \\
\text { group }\end{array}$ & $\begin{array}{c}\text { Mean of recovery } \\
\text { time of } 2 \text { days group }\end{array}$ & $p$ value \\
& $2,9 \mathrm{~cm}$ & $-3,7 \mathrm{~cm}$ & 0,000 \\
$\begin{array}{l}\text { Difference mean of vertical } \\
\text { jump before and after } \\
\text { recovery time }\end{array}$ & & & \\
\hline
\end{tabular}

In this study, the research subjects were induced fatigue through the simulation procedure of a soccer match at time intervals like a football match in general. A soccer match simulation adapted from research conducted by Russel et al (2011), can provide the same fatigue effect on each research subject without being influenced by the original playing position of the research subject. The study subjects were divided into 2 treatment groups in the form of recovery time for 2 days as insufficient recovery time and 5 days as sufficient recovery time. The division of this group is based on the role of recovery time on risk factors for injury to football athletes after the match (Bengtsson et al, 2018).

The aim of the research to examine the effect of recovery time after the match on the leg muscle explosive. The key findings from the present study were Table 3 shows that the group that received recovery time for 5 days had an average vertical jump difference after and before the recovery period was higher than the group that received recovery time for 2 days. The unpaired $t$ test conducted in the two treatment groups showed $\mathrm{p}<0.05$ which stated that there was a significant difference in the average vertical jump difference after and before the recovery period between the two groups. This is in line with previous studies by Arruda et al (2015) that there was a significant decrease in the ability to run acceleration on soccer players after getting a busy match schedule with a short recovery time. Post-game performance recovery and inflammatory adaptations in response to a three-game weekly microcycle (Sunday, Wednesday and Sunday) displayed a different response pattern, with strong indications of greater physiological stress and fatigue after the middle game that was preceded by only a 3-day recovery period8. That insufficient recovery time between matches may cause performance deterioration and an increase in the risk of injury (Nedelec, 2016; Paul, 2016; Jimenez, 2017).

In this study, fatigue in research subjects was induced through competition simulation which gave the same fatigue effect as the competition in general. Fatigue on soccer related with Exercise Induced Muscle Damage (EIMD). Together with a decline in performance, long-term muscle damage and increased levels of intramuscular enzymes and inflammatory markers are reported following soccer competition. This fatigue condition is caused by dehydration, glycogen depletion, muscle damage, and mental fatigue (De Hoyo et al, 2016; Djaoui, 2016; Finsterer et al, 2016). 
Glycogen in the muscles is the main source of energy used to move the muscles, when the glycogen in the muscles runs out, there arises fatigue (Bessa, 2016; Sparks, 2016). The condition of fatigue will result in a decrease in strength or ability in its performance resulting in a decrease in performance or the performance provided is not optimal. If muscle glycogen is not sufficient, the muscle's ability to contract will also be reduced due to the lack of energy sources obtained. This will result in decreased muscle strength. Decreased muscle strength will also affect the explosive power of muscles because muscle strength is a factor that affects muscle explosive power (Jimenez, 2017; Fitzpatrick, 2019).

The condition of muscle glycogen depletion takes time to restore glycogen reserves to be used again in the activity so that it takes sufficient recovery time to restore the amount of glycogen in the muscles to normal again. Glycogen depletion conditions can last for 2-3 days. During the recovery period there is an expenditure from the accumulation of lactic acid, restoration of energy reserves, recovery of oxygen reserves, and repair of tissue damaged due to competition (Burke et al, 2016). Soccer players usually need 48-72 hours to restore metabolic homeostasis, muscle trauma and anaerobic performance decrements. It takes about 48-72 hours after heavy activity to restore energy that has been used in activities with high loads and during the recovery time activities that should not be carried out with high loads. (Scutch et al, 2016; Jimenez et al, 2017).

\section{CONCLUSION}

The conclusion of this study is that there is an effect of recovery time after the game on the leg muscle explosive power in soccer athletes. Recovery time of 5 days is better than 2 day after competition. It is very important to pay attention to recovery time in athletes, the recommendation of this study is a minimum of 5 days.

\section{REFERENCES}

Arruda, A. F., C. Carling, V. Zanetti, M. S. Aoki, A. J. Coutts, dan A. Moreira. 2015. Effects of a Very Congested Match Schedule on Body-Load Impacts, Accelerations, and Running Measures in Youth Soccer Players. International Journal of Sports Physiology and Performance. 10(2): 248-252. [DOI: 10.1123/ijspp.2014-0148]

Bengtsson, H., J. Ekstrdan, M. Waldén, dan M. Hägglund. 2018. Muscle Injury Rate in Professional Football is Higher in Matches Played Within 5 Days Since The Previous Match: A 14Year Prospective Study With More Than 130.000 Match Observations. Br J Sports Med. 52(17): 1116-1122. [DOI: 10.1136/bjsports-2016-097399.]

Bessa, A.L., Oliveira, V.N., Agostini, G.G. 2016. Exercise Intensity and Recovery: Biomarkers of Injury, Inflammation and Oxidative Stress. J Strength Cond Res. 2016; 30(2): 311-9. [http://dx.doi.org/10.1519/JSC.0b013e31828f1ee9] [PMID: 23604000] 
Burke, L. M., L. J. van Loon, dan J. A. Hawley. 2016. Postexercise Muscle Glycogen Resynthesis in Humans. Journal of Applied Physiology. 122(5):1055-1067. [DOI: 10.1152/japplphysiol.00860.2016]

Carling, C., Bradley, P., McCall, A., Dupont, G. 2016. Match-to-Match Variability in High-Speed Running Activity in a Professional Soccer Team. J Sports Sci; 34(24): 2215-23. [http://dx.doi.org/10.1080/02640414.2016.1176228] [PMID: 27144879]

De Hoyo, M., Cohen, D.D., Sañudo, B. 2016. Influence of Football Match Time-Motion Parameters on Recovery Time Course of Muscle Damage and Jump Ability. J Sports Sci; 34(14):1363-70.[http://dx.doi.org/10.1080/02640414.2016.1150603] [PMID: 26930226]

Djaoui, L., Diaz-Cidoncha, G. J., Hautier, C., Dellal, A. 2016. Kinetic Post-match Fatigue in Professional and Youth Soccer Players During The Competitive Period. Asian J Sports Med; 7(1): e28267. [ doi: 10.5812/asjsm.28267] [PMID: 27217927]

Finsterer, J., Drory, V.E. 2016. Wet, Volatile, and Dry Biomarkers of Exercise-Induced Muscle Fatigue. BMC Musculoskelet Disord; 17: 40. [http://dx.doi.org/10.1186/s12891-016-08692] [PMID: 26790722]

Fitzpatrick, J. 2019. Sensitivity and Reproducibility of a Fatigue Response in Elite Youth Football Players. Science and Medicine in Football Volume 3, 2019 - Issue 3. [https://doi.org/10.1080/24733938.2019.1571685]

Guyton, A. C., dan J. E. Hall. 2016. Guyton and Hall Textbook of Medical Physiology. 13th ed. Philadelphia (PA): Elsevier.

Jimenez, D.M. Gonzales, J. C. 2017. Fatigue and Recovery in Soccer: Evidence and Challenges. The Open Sports Sciences Journal 10, (Suppl 1: M5) 52-70.[DOI: 10.2174/1875399X01710010052]

Larsen, J. V. L., Dalgas, U., Andersen, T. B., 2018. Position-Specific Acceleration and Deceleration Profiles in Elite Youth and Senior Soccer Players. J Strength Cond Res Apr; 32(4):11141122. [DOI: 10.1519/JSC.0000000000001918.]

Schimpchen, J., Skorski, S., Nopp, S., Meyer, T. 2016. Are Classical Tests of Repeated-Sprint Ability in Football Externally Valid? A New Approach to Determine In-Game Sprinting Behaviour in Elite Football Players. J Sports Sci; 34(6): 519-26. [DOI: 10.1080/02640414.2015.1112023] [PMID: 26580089]

Schuth, G., Carr, G., Barnes, C., Carling, C., Bradley, P.S. 2016. Positional Interchanges Influence The Physical and Technical Match Performance Variables of Elite Soccer Players. J Sports Sci; 34(6): 501-8.[http://dx.doi.org/10.1080/02640414.2015.1127402] [PMID: 26700131]

Nedelec, M., McCall, A., Carling, C., Legall, F., Berthoin, S., Dupont, G. 2016. The Influence Of Soccer Playing Actions On The Recovery Kinetics After a Soccer Match. J Strength Cond Res; 28(6): 1517-23.[http://dx.doi.org/10.1519/JSC.0000000000000293] [PMID: 24172722] 
Paul, D.J., Bradley, P.S., Nassis, G.P. 2106. Factors Affecting Match Running Performance of Elite Soccer Players: Shedding Some Light on The Complexity. Int J Sports Physiol Perform; 10(4): 516-9.[http://dx.doi.org/10.1123/ijspp.2015-0029] [PMID: 25928752]

Skala Survei Indonesia (SSI). 2014. Jenis Olahraga yang Paling Disukai Publik Indoneisa. https://skalasurvei.com/jenis-olah-raga-yang-paling-disukai-publik-indonesia/.[Diakses pada 7 Januari 2019].

Smith, M.R., Zeuwts, L., Lenoir, M., Hens, N., De Jong, L.M., Coutts, A.J. 2016. Mental Fatigue Impairs Soccer-Specific Decision-Making Skill. J Sports Sci; 34(14): 1297-304. [http://dx.doi.org/10.1080/02640414.2016.1156241] [PMID: 26949830]

Smith, M.R., Coutts, A.J., Merlini, M., Deprez, D., Lenoir, M., Marcora, S.M. 2016. Mental Fatigue Impairs Soccer-Specific Physical and Technical Performance. Med Sci Sports Exerc, 48(2): 267-76.[http://dx.doi.org/10.1249/MSS.0000000000000762] [PMID: 26312616]

Sparks, M., Coetzee, B., Gabbett, T.J. 2016. Variations In High-Intensity Running and Fatigue During Semi-Professional Soccer Matches. Int J Perf Anal Sport, 16(1): 122-32. [DOI: $\underline{10.1080 / 24748668.2016 .11868875}$ ]

Vitale, K., Getzin, A. 2019. Nutrition and Supplement Update for The Endurance Athlete: Review and Recommendations. Nutrients Jun 7;11(6):1289. [DOI: 10.3390/nu11061289]

Wong, J. D., M. F. Bobbert, A. J. van Soest, P. L. Gribble, dan D. A. Kistemaker. 2016. Optimizing The Distribution of Leg Muscles for Vertical Jumping. PloS One.11(2): 1-15. [https://doi.org/10.1371/iournal.pone.0150019] 